\title{
O PAPEL DO CONSUMO DOS MEDIA PELOS JOVENS PORTUGUESES NA EMERGÊNCIA DE UMA CONSCIÊNCIA EUROPEIA
}

\author{
THE ROLE OF MEDIA CONSUMPTION BY YOUNG PORTUGUESE IN THE \\ EMERGENCE OF A EUROPEAN CONSCIOUSNESS
}

\author{
EL PAPEL DEL CONSUMO DE LOS MEDIOS POR LOS JÓVENES \\ PORTUGUESES EN LA EMERGENCIA DE UNA CONCIENCIA EUROPEA
}

\author{
Lídia Oliveira \\ Universidade de Aveiro-Portugal \\ lidia@ua.pt \\ Carlos Reis \\ Universidade de Aveiro \\ cmareis@gmail.com \\ Vania Baldi \\ Universidade de Aveiro \\ vbaldi@ua.pt
}

\section{Resumo}

Qual o papel dos media na construção da consciência europeia dos jovens portugueses? Os jovens de hoje estão permanentemente imersos em dinâmicas de consumos culturais ambivalentes: suspensos entre as experiências da apropriação, da partilha e do simples entretenimento mediático. Estão colocados, portanto, numa aparente situação privilegiada de acesso aos variados conteúdos culturais e ao estabelecimento de relacionamentos transfronteiriços. Em potência a vivência neste contexto mediático deveria incrementar o conhecimento que os jovens europeus, (e os jovens portugueses em particular) detêm uns dos outros e ser uma oportunidade para o desenvolvimento do respeito, do reconhecimento e curiosidade mútuo, do pluralismo, da liberdade e da cooperação. Existirá um uso especificamente europeu da linguagem transversal dos media, capaz de tornar os jovens europeus mais próximos apesar da pluralidade linguística e sociocultural de cada país, de modo particular os jovens portugueses?

Palavras-chave: Media, Bens Culturais, Consciência Europeia, Jovens Portugueses, Juventude 


\begin{abstract}
What is the role of media in building the awareness of young European Portuguese? Young people today are constantly immersed in the dynamics of consumption of media content, from television to the Internet, which puts them in a privileged position of access to cultural content and the establishment of cross-border relationships. In this context the experience power media should increase awareness that young Europeans (and the young Portuguese in particular) have each other and be an opportunity to develop respect, mutual recognition and curiosity, pluralism, freedom and cooperation. Does the language of media language shared by young people across Europe that enhances their approach despite the linguistic and sociocultural diversity of each country, especially the young Portuguese?
\end{abstract}

Keywords: Media, Cultural Heritage, European awareness, Youth

\title{
Resumen
}

¿Cuál es el papel de los mass media en la construcción de la conciencia europea de los jóvenes portugueses? Los jóvenes de hoy están permanentemente inmersos en las dinámicas de consumo culturales ambivalentes: inmersos entre las experiencias de participación, del intercambio y de los medios tradicionales de entretenimiento mediático. Están colocados por tanto en una aparente posición privilegiada del acceso a los diversos contenidos culturales y al establecimiento de las relaciones transfronterizas. En este contexto mediático, la experiencia debería incrementar el conocimiento que los jóvenes europeos (y en particular entre los jóvenes portugueses) tienen unos de los otros y ser una oportunidad para el desarrollo del respeto, del reconocimiento y la curiosidad mutua, del pluralismo, de la libertad y de la cooperación. ¿Existirá un uso exclusivamente europeo del lenguaje transversal de los media, capaz de cambiar a los jóvenes europeos más cercanos a pesar de la pluralidad lingüística y sociocultural de cada país, sobretodo en los jóvenes portugueses?

Palabras clave: Medios de comunicación, Patrimonio cultural, Conciencia europea, Juventud portugués, Juventud

\section{INTRODUÇÃO}

Serão os media europeus capazes de despertar nos jovens portugueses o surgimento de uma consciência europeia? Será que os jovens portugueses sentem necessidade de se sentirem europeus? Será a Europa um elo forte de ligação entre os jovens europeus? Despertará ela interesse no devir de uma "comunidade de destino", como referia Edgar Morin? Será a linguagem dos media uma linguagem capaz de veicular para os jovens europeus uma literacia cívica e cultural que vise a aproximação, apesar da pluralidade linguística e Sociocultural de cada país? 
Os jovens vivem imersos em atuações multíplices e ambivalentes de consumo mediático. Através da integração da comunicação de massa com a comunicação em rede os jovens experimentam diferentes práticas de conhecimento e de interação, que em quanto assinalarem um grande leque de oportunidades, ao mesmo tempo fragmentam o sentido destas experiências. Televisão, internet, redes sociais, rádio, imprensa, música, videojogos ou cinema podem oferecer as condições de experiências para uma consciência e uma sociabilidade cosmopolita, ou pelo menos podem fornecer um sentimento de vizinhança e proximidade imaginaria entre culturas distintas.

Nesta dialética entre sujeitos - informações - comunidades, importa compreender a relevância específica que os media exercem na forma de desenvolver e aproximar os jovens para uma consciência comum, de si e da Europa. É objetivo apresentar os resultados da investigação baseada em focus group, sobre a influência e o papel que os media (a televisão, os jornais, a rádio e a Internet), têm na aproximação dos jovens portugueses à problemática do Ser Europeu. Ou seja, sobre a influência que a relação com os media supracitados, por parte dos jovens portugueses, tem na sua percepção da Europa, como, perspectivar, em que medida os media podem ser potenciadores de uma nova emergência de Consciência Europeia.

Neste sentido pretende-se compreender, através duma metodologia articulada entre entrevistas, focus group e comparações teoréticas sobre este tema assim multiestratificado, se os media são, ou não, potenciais reveladores e promotores da compreensão que os jovens europeus, e em concreto os jovens portugueses, vão possuindo: da Europa, de uns com os outros e de si próprios.

\section{A JUVENTUDE: CONCEITO, DEFINIÇÕES E IDENTIDADE}

O conceito de juventude é considerado por muitos autores e instituições como uma fase da vida humana prévia à idade adulta. Segundo Santos (2011, p. 1) trata-se de um processo de passagem definido, em grande medida, em relação a uma dupla inserção social: profissional (término da escolaridade) e conjugal (independência econômica e residencial face à família). A mesma autora refere ainda que é um período em que ocorrem transformações sexuais, cognitivas e sociais, que marcam quatro esferas do desenvolvimento do indivíduo: o corpo, o pensamento, a vida social e a representação de si (“construção identitária”). Nesta análise 
iremos partir destes quatro pontos para traçar, ainda que de modo sucinto, uma perspectiva atual daquilo que é entendido como "juventude".

A juventude implica uma "mudança de corpo", como um conjunto de transformações físicas que ocorrem na puberdade e que se refletem para a vida adulta. Estas transformações (maturação física do corpo humano) capacitam os indivíduos a adaptarem-se no mundo de um modo diferente daquele que, anteriormente, dependiam, pela ligação aos seus progenitores. Os jovens ficam aptos a realizarem todo um conjunto de funções específicas e próprias dos adultos, que pressupõem a autonomia e a auto-realização próprias desta fase. Embora o corpo humano estar em contínua mutação, é na juventude que culminam as principais transformações fisiológicas nos indivíduos. Importa ainda referir o corpo como meio de comunicação do indivíduo com os outros e com o mundo. Os problemas gerados por valores estéticos e éticos encontram no corpo humano uma perspectiva pessoal e social, objetiva e subjetiva que infere o modo do jovem ver o seu corpo e no modo como os outros o veem. Este aspecto é importantíssimo, no sentido em que os valores de autoestima e satisfação, nesta fase etária são essenciais na preparação do jovem para o seu estado adulto.

Interessa, também, neste ponto abordar a questão da "idade da juventude", embora esta definição não seja tão objetiva e consensual quanto desejaríamos. As Nações Unidas entendem a juventude como a faixa etária compreendida entre os 15 e os 24 anos de idade ${ }^{1}$, com a salvaguarda de que cada país, de acordo com a sua realidade pode estabelecer o seu intervalo $^{2}$. A União Europeia estabelece esta mesma faixa etária para designar a juventude, embora o término não seja fixado nos 24 anos, mas sim nos 25 anos de idade (EUROPEIA C. D. C., 2001). Um estudo realizado pela Viacom Brand Solutions International (VBSI) ${ }^{3}$ com o título "Youth No Longer Defined by Chronological Age; Consumers Stay 'Younger' Longer" refere que atualmente existem três Etapas da Juventude. A fase da "Descoberta" (16 aos 19

\footnotetext{
${ }^{1}$ Resolução 40/41 (1985) e 50/81 (1995) da Assembleia-Geral das Nações Unidas. (ONU, 1995 )

${ }^{2}$ A Assembleia Geral da ONU definiu a juventude, pela primeira vez, em 1985 para o Ano Internacional da Juventude. Ao subscrever as diretrizes para o planejamento posterior e o acompanhamento adequado no sector da juventude, a Assembleia, para fins estatísticos, definiu como jovens as pessoas entre os 15 e os 24 anos, sem prejuízo de outras definições de Estados Membros. No entanto, acrescentou que, para além da definição estatística do termo juventude referida atrás, o sentido do termo juventude variava em diferentes sociedades em todo o mundo e que as definições de juventude haviam mudado continuamente como resposta a flutuações das circunstâncias políticas, econômicas e socioculturais, in: http://www.unric.org/html/portuguese/ecosoc/youth/Jovens-3.pdf (UNIRC, 2001)

${ }^{3}$ MarketingCharts staff (2008) Youth No Longer Defined by Chronological Age; Consumers Stay 'Younger' Longer - http://www.marketingcharts.com/topics/asia-pacific/youth-no-longer-defined-by-chronological-age-35is-new-18-6530/
} 
anos); a fase da "Experimentação (20 aos 24 anos) e a fase de "Ouro" (25 aos 34 anos) (International, 2008). Importa notar aqui que a "idade da juventude" vai-se prorrogando, isto é vai-se alargando no tempo e no espaço de vida e na percepção que os jovens e a sociedade vão tendo dela. Nesta linha de pensamento refira-se também que muitos especialistas pretendem entender, quando se servem de uma expressão utilizada pela literatura inglesa "adultescent" para se referirem a algo vivenciado por algumas pessoas entre 35 e 45 anos (Pereira, 2010, p. 41). Segundo a mesma autora estes indivíduos mantêm um estilo de vida próprio dos adolescentes, adiando responsabilidades e deveres que se esperam dos adultos, vivendo (...) uma "juventude estendida". No estudo referido anteriormente (International, 2008) importa reter a seguinte frase em jeito de conclusão:

"Contemporary youth should now be defined as 'the absence of functional and/or emotional maturity,' reflecting the fact that accepting traditional responsibilities such as mortgages, children and developing a strong sense of self-identity/perspective is occurring later and later in life."

Nesta comunicação iremos delimitar a faixa etária da juventude adotada e definida pela União Europeia, sendo esta, no geral, a de maior consenso nos estudos analisados. No entanto, esta convenção não é suficiente para entender os indivíduos que se situam nesta faixa etária, pois a juventude não é só uma característica etária, como vimos, mas encerra em si todo um conjunto de práticas e vivências sociais multifacetadas.

Considerando as características psicológicas deste estado juvenil, observa-se que existem, atualmente, múltiplas propriedades que estão associadas à realidade juvenil. Numa análise, ainda que sumária, feita por Santos (2011), pode-se descobrir que existe no jovem

"motivação para seguir tendências; receptividade a novos produtos; adesão a estilos de vida; atractividade pelo consumo; afinidade com marcas e valorização da posse de flexibilidade monetária". Refere ainda que "os jovens são receptores particularmente sensíveis, vulneráveis, influenciáveis e crédulos". Diz também que a juventude é um período de vida marcado por factores de mudança e transição, assim com se caracteriza também "por ser uma fase de adaptação, insatisfação (rejeição de antigas formas de pensar) e inovação" (SANTOS, 2011, p. 1).

\footnotetext{
4 “A juventude contemporânea deve agora ser definida como 'a ausência de maturidade funcional e / ou emocional', refletindo o fato de como aceitar responsabilidades tradicionais, tais como hipotecas, as crianças e desenvolvendo um forte sentido de auto-identidade/perspectiva, ocorrem cada vez mais tarde na vida" (Trad. dos autores).
} 
Filósofos e teorizadores sociais, como Edgar Morin e Pierre Bourdieu contribuem, também, para uma definição de juventude, como "fenômeno social" (Pereira, 2010, p. 39). Este fato incorpora o modo como a sociedade vê os jovens, no seu devir existencial e social, assim como sente com eles e se "personaliza" neles. Relativamente à condição social da juventude, autores como Hack e Pires (2005, p. 5) referem que "a juventude é uma concepção, representação ou criação simbólica, fabricada pelos grupos sociais ou pelos próprios indivíduos tidos como jovens, para significar uma série de comportamentos e atitudes a ela atribuídos". Segundo estas autoras, a juventude é um período "não apenas de limites etários pretensamente naturais e objetivos, mas também, e principalmente, de representações simbólicas e situações sociais com suas próprias formas e conteúdos, que tem importante influência nas sociedades modernas". Dizem ainda outros autores que a juventude é uma "condição social que se constituí histórica e socialmente" (CRUZ, SERUYA, REIS, \& SCHMIDT, 1984, p. 285). Deste modo, entende-se que o acesso dos indivíduos a essa condição social, traz consigo desigualdades e diferenças próprias, consoante o ritmo e o condicionamento que cada jovem contém no seu devir existencial. Uma característica interessante é aquela que nos é dada por Fernando Santos (2004), quando compara os jovens de vários continentes, para dizer que:

\begin{abstract}
"o comportamento da juventude está condicionado pelas condições económicas, de desenvolvimento e culturais pelo que o perfil de comportamento salienta as semelhanças entre jovens da mesma região geográfica distinguindo-os dos que pertencem a outros continentes, europeus, asiáticos e africanos. Porém, as preferências e mais ainda as expectativas em relação ao futuro, são partilhadas pelos jovens independentemente do seu país de origem. As diferenças entre jovens de sexo oposto, embora ainda permaneçam sobretudo relativamente no consumo, estão a diminuir em todos os países e deixam quase de ser relevantes ao nível de muitos dos valores e das ambições." (p. 9)
\end{abstract}

Relativamente à representação de si (construção identitária da personalidade), Santos (2011, p. 2) refere que é na "adolescência que se desenrola, no sujeito, a consciência de estar situado na sociedade que o rodeia, encontrando-se num ciclo particularmente vulnerável às imagens de si que lhe são reenviadas pelos que o circundam”. Nessa fase o indivíduo é permanentemente chamado a "falar de si para si" (auto percepção) e a "ouvir de si pelos outros" (hetero percepção). Nessa linha de pensamento podemos referir o surgimento de uma consciência individual que se vai formando à medida que o indivíduo se vai conhecendo e se 
vai relacionando com os outros, num tempo e espaço próprios. Como refere E. Coreth (1986, p. 20) "a essência do homem manifesta-se no seu modo de agir: no seu comportamento ativo, na sua atitude em relação a tudo o que no seu mundo lhe vem ao encontro ou exerce influência nele". Por outras palavras podíamos dizer que o sujeito se conhece (o EU) a partir da percepção e da informação que vai recolhendo dos outros, ao mesmo tempo que vai formulando esse conhecimento em informação de si, em consciência de si. Esta representação da identidade, esta consciência de si (do sujeito, do EU, do jovem) só existe, como refere Coreth (1986) em atos conscientes: "Quando eu conheço, sei que conheço; quando quero, sei que quero".

\section{Os JOVEnS Portugueses}

Fazendo um quadro da atual situação socioeconómica e cultural, vivida pelos jovens portugueses, pode referir-se que o panorama não é muito estimulante e tranquilizante. Assim como em outros países, mas com variáveis consoantes às especificidades históricas e contextuais do seu país, os jovens portugueses vivem momentos de desconsolo e muitas vezes de indiferença resignada perante a atual conjuntura.

O fim de um curso acadêmico e consequentemente o desejo de ingressar no mercado de trabalho perspectiva-se cada vez mais tardio e difícil. Os jovens portugueses desejam a autonomia econômica, no entanto o "deixar-se ficar" em casa dos pais parece ser a única saída possível e momentânea a considerar. No Norte da Europa, refere Pereira (2010) "as bolsas de estudos são mais prevalentes e os critérios para as obter menos rigorosos, e onde existe uma verdadeira proteção social, é considerado anormal um jovem viver com os pais". Os jovens portugueses referem-se a estas contingências como necessárias para poderem singrar, pois em muitos casos o aumento de formação não é acrescido com um aumento de ofertas de emprego, pelo contrário. Vê-se, atualmente, muitos jovens portugueses licenciados a trabalhar em call's center's (PEREIRA, 2010), pois não encontram outro meio de realizar a sua autonomia econômica. Outros, porém consideram a oportunidade em continuar a sua formação acadêmica, em grande parte ajudados pelo background familiar que os sustenta e os apoia.

Dentro desta polêmica pode mencionar-se um caso recente da sociedade portuguesa, que manifestou o seu "mal-estar social", no "Protesto Geração à Rasca". Esta foi uma 
oportunidade para os jovens e não só, expressarem as suas inquietações e inseguranças face ao futuro, que avizinham cada vez mais "triste e cinzento". Alguns jornalistas que fizeram a reportagem desse dia referem que esta manifestação "foi inicialmente convocada por quatro jovens, através da Internet, para Lisboa e Porto, como um manifesto apelando à participação de "desempregados, 'quinhentoseuristas" ${ }^{5}$ e outros mal remunerados, escravos disfarçados, subcontratados, contratados a prazo, falsos trabalhadores independentes, trabalhadores intermitentes, estagiários, bolsistas, trabalhadores-estudantes, estudantes, mães, pais e filhos de Portugal" (ALVAREZ, RIBEIRO, \& BARBOSA 2011). Em Portugal os jovens acreditam que por terem um nível de formação acadêmica superior isso lhes garante o acesso a emprego e habitação própria. Como refere Pereira (2010) "nunca foi tão difícil encontrar um emprego estável como hoje. Apesar de, em média, terem mais habilitações curriculares do que as gerações que os precederam, os jovens portugueses de hoje, correm o sério risco de se tornarem numa geração sem esperança".

Como forma de escape, de evasão, de saída, muitos jovens portugueses colocam a hipótese de emigrar e de estudar em outros países da Europa, como condições para auferir, num futuro próximo, de melhores condições econômicas. Segundo o estudo realizado em Maio de 2011 pelo Eurobarómetro Flash sobre «Juventude em Movimento», 55\% dos jovens portugueses colocam a hipótese de emigrar para trabalhar noutro país europeu, embora 32\% dos mesmos considere esta hipótese por um curto espaço de tempo. No mesmo estudo, 38\% dos jovens diz não querer emigrar (EUROPEIA C., 2011). No entanto o principal obstáculo à deslocação para o estrangeiro continua a ser de ordem financeira, diz o mesmo estudo.

\section{AS DIMENSÕES dA CONSCIÊNCIA (CRÍTICA, REFLEXIVA E PRÁTICA)}

Para definir a consciência, recorremos às seguintes propostas de definição:

"Consciência - "Em geral, a possibilidade de dar atenção aos próprios modos de ser e às próprias ações, bem como de exprimi-los com a linguagem. Essa possibilidade é a única base de fato sobre a qual foi edificada a noção filosófica de consciência." (ABBAGNANO, 1998, p.185)

Consciência - "Do latim conscientia (...) significa etimologicamente um saber testemunhado ou concomitante. Por analogia, dualidade ou

\footnotetext{
${ }^{5}$ É a designação adquirida por aquela camada social que não consegue ganhar mais que 500 euros por mês. 
multiplicidade de saberes ou de aspectos num mesmo e único acto de conhecimento. Psicologicamente e em sentido restrito, a Consciência designa o conhecimento concomitante ou cumulativo dos próprios actos ou estados internos no preciso momento em que são vividos ou experimentado. $\mathrm{Na}$ medida em que experimentamos e vivemos os nossos actos ou estados internos para além do conhecimento do conteúdo objectivo de que são portadores, sabemos que eles existem, temos deles consciência. A Consciência envolve, portanto, um duplo saber ou um saber cumulativo: é um saber de algo que como tal se sabe." (FREITAS, 1989, p.1130)

No contexto da investigação que visa compreender em que medida o consumo dos media e dos bens culturais contribuem para a formação da consciência europeia dos jovens portugueses, nos contextos de entrevistas e de focus group, foram inquiridos e estimulados a debater sobre a percepção que têm sobre a Europa, de modo particular da União Europeia (EU), isto é, na tentativa de compreender que consciência, possuem os jovens portugueses da realidade europeia. A resposta é a questão central desta comunicação. Por ser importante clarificar e entender o que os jovens pensam sobre esta problemática, importa antes de mais perceber, neste capítulo, o que significa a consciência. E. Coreth (1986) refere que a consciência é o que vemos e apreendemos através das coisas e dos fatos com que nos deparamos e relacionamos com eles, ajuizando-os, desejando-os e utilizando-os (p. 93). Refere ainda que todo o ato consciente é "intencional", quer dizer orientado para algo como seu conteúdo ou objeto. Esta perspectiva é muito importante quando abordarmos a questão do consumo dos media na formação da consciência europeia dos jovens portugueses, isto é, perceber se existe intenção de fato em consumir e se esse consumo dos media potenciam o seu conhecimento da realidade europeia e contribuem para a sua formação. Refiro para terminar aquilo que Coreth diz sobre o conhecer:

"só conheço "algo" quando eu o reconheço, isto é, quando na própria realização e através do ato de conhecer estabeleço uma mediação de mim em relação ao objeto. Isto não acontece só nos atos de conhecimento puramente teórico, mas também na lida prática com as coisas, na avaliação e na ambição, mas sempre na realização dos meus próprios atos. Isto mostra que a nossa consciência objetiva está condicionada e sustida pela consciência da realização. Sempre que eu vejo alguma coisa, sei que vejo. Sempre que pergunto, sei que pergunto. Sempre que sei alguma coisa, sei que a sei” (CORETH, 1986, p. 94).

Dessa reflexão deduz-se que a consciência possui características e qualidades, que no caso do presente estudo classificamos de consciência reflexiva, crítica e prática. Nessa 
reflexão partiu-se do particular para compreender o geral, isto é compreender a consciência no seu todo. Deste modo, entende-se existir uma consciência reflexiva que capacita o indivíduo a ver a realidade, isto é, como a vê no seu todo. É o modo como o sujeito pensa e interroga a realidade e se questiona sobre a existência. A consciência crítica habilita o indivíduo a julgar a realidade, perante aquilo que previamente observou. Aqui o sujeito procura encontrar resposta às interrogações antes lançadas pela consciência reflexiva. As apreciações que o indivíduo faz da realidade potenciam-no para a ação, para o agir. Aqui entramos na chamada fase da consciência prática, ou seja, a pessoa humana, depois de ver e julgar a realidade, age numa relação dialética homem-mundo. Importa referir que a consciência reflexiva e crítica estão intimamente ligadas, isto é, pertencem ao campo do conhecimento puramente teórico, enquanto a consciência prática parte das anteriores para se poder realizar e expressar no mundo. Por outras palavras, a consciência reflexiva e crítica geram os meus pensamentos e a apreensão que vou tendo de mim e da realidade que me circunda, ao passo que a consciência prática faz-me agente dessa tomada de conhecimento, gera os meus atos, o meu modo de agir (modus vivendi).

Neste estudo iremos usar estas três dimensões da consciência como instrumentos heurísticos para compreender como é que os jovens portugueses estruturam a sua tomada de consciência sobre a Europa. Esta orientação teórica sobre as três dimensões da consciência foi utilizada, nos Focus Groups, como quadro conceptual para observar como é que os jovens portugueses apreendem a realidade da União Europeia, através do consumo dos media e dos bens culturais.

\section{A CONSCIÊNCIA EUROPEIA}

Na Carta dos Direitos Fundamentais da União Europeia, pode ler-se no preâmbulo as seguintes afirmações:

"os povos da Europa, estabelecendo entre si uma união cada vez mais estreita, decidiram partilhar um futuro de paz, assente em valores comuns. Consciente do seu património espiritual e moral, a União baseia-se nos valores indivisíveis e universais da dignidade do ser humano, da liberdade, da igualdade e da solidariedade; assenta nos princípios da democracia e do Estado de direito. Ao instituir a cidadania da União e ao criar um espaço de 
liberdade, de segurança e de justiça, coloca o ser humano no cerne da sua acção.” (EUROPEIA C., 2000, p. 8)

A Comissão Europeia na Resolução do Parlamento Europeu, de 2 de Abril de 2009, sobre a consciência europeia e o totalitarismo, refere que:

"o processo de integração europeia é um êxito, na medida em que permitiu a construção de uma União Europeia que abarca hoje os países da Europa Central e Oriental que viveram sob regimes comunistas desde o final da Segunda Guerra Mundial até ao início dos anos 1990, e que as anteriores adesões da Grécia, da Espanha e de Portugal, que sofreram com regimes fascistas de longa duração, contribuíram para garantir a democracia no Sul da Europa". Considera a mesma Comissão que "a Europa não estará unida enquanto não for capaz de lograr uma visão comum da sua História, de reconhecer o nazismo, o estalinismo e os regimes fascistas e comunistas como um legado comum e de levar a cabo um debate honesto e exaustivo sobre os seus crimes cometidos no século passado. (...) Reafirma o seu empenho numa Europa pacífica e próspera assente nos valores do respeito da dignidade humana, da liberdade, da democracia, da igualdade, do primado do Direito e do respeito pelos direitos humanos e (...) declara que a integração europeia, enquanto modelo de paz e reconciliação, representa uma escolha livre dos povos da Europa para se comprometerem na via de um futuro partilhado e que cabe à União Europeia a especial responsabilidade de promover e salvaguardar a democracia, o respeito dos direitos humanos e o Estado de Direito, tanto dentro como fora da União Europeia."(EUROPEIA C., 2009)

Através desta resolução pode observar-se o ideário que permeia o que a Comissão Europeia entende sobre a Consciência Europeia. Sintetizando, para este órgão de soberania da União Europeia, importa reforçar os valores da paz, do respeito pela dignidade humana, da democracia, da liberdade, da igualdade, do respeito pelos direitos humanos, recordar e assumir a história da Europa e fazê-la gênese de um novo começo, para compreender e aceitar esta realidade, essa consciência comum. Pode-se dizer ainda que esta declaração sobre o significado da Consciência Europeia dentro da União Europeia só é possível subsistir na medida em que existir mútua aceitação entre os povos das suas diferenças (cultura, história, liberdade, direitos e deveres) que potenciam esta união e esta "irmandade". Edgar Morin refere que a Europa é uma comunidade de destino comum, quando "anseia" por uma "federação europeia" que diz ainda não ser um desígnio comum, mas um destino comum que está em gestação desde 1945.

"Embora ele não seja ainda visível à maior parte dos europeus, ele impõe-selhes, apesar de todas as diferenças ou desigualdades de situações e de 
problemas. Destino comum: Ao suportar os mesmos factores de decadência e de decomposição e de não poder resistir-lhes senão de maneira comum; Ao suportar os mesmos perigos nas identidades, diversidades, e verdades culturais; Ao suportar uma ameaça certa e incerta com dois rostos extremos (exterminacionismo e totalitarismo). Nós estamos confrontados com o mesmo problema: não morrer, não só zoologicamente, mas também politicamente, culturalmente, intelectualmente. Chegamos ao momento da comunidade de destino." (MORIN, 1988, p. 133).

É a partir daqui, com estes referenciais, que poderemos descobrir se esta consciência europeia é e está enraizada nos jovens e em particular nos jovens portugueses. Repare-se que em nenhum dos pontos abordados pela Comissão Europeia se falou de dinheiro, de moeda única, de euros para referir esta consciência europeia. Leem-se valores, história, dignidade, paz, liberdade, mas não economia. Coloca-se a questão: Terão os jovens portugueses esta percepção? Aceitarão eles mais o ideário proposto pela Comissão Europeia acerca da consciência europeia ou serão os "meios mais práticos" (moeda única, livre circulação de bens, mobilidade) que farão nos jovens aceitar essa consciência de pertença à União Europeia?

\section{AS DIMENSÕES DA CONSCIÊNCIA EUROPEIA}

Fazendo a síntese com as anteriores dimensões da consciência podemos dizer que, no estudo em questão quando se refere consciência reflexiva se entende a qualidade da consciência que capacita os jovens portugueses a pensarem numa União Europeia diferente da que temos atualmente, numa União Europeia feita de expetativas, utopias e esperanças. Aqui se observa o que os jovens portugueses veem da realidade da União Europeia. Quando se aborda a questão da consciência crítica nos jovens portugueses, reporta-se a qualidade da consciência dos jovens enquanto seres pensantes que julgam a sua relação de pertença à União Europeia, isto é, que constroem cenários de crítica, de rejeição e aceitação, face às atuais conjunturas (políticas, econômicas, sociais e culturais) dos Estados-Membros. Finalmente, quando se refere à consciência prática nos jovens referem-se os motivos que levam os jovens a participar ou não na construção do projeto europeu. Todas essas qualidades da consciência formam um todo, articulado e complexo, na reflexão e não partes isoladas da mesma. $\mathrm{O}$ fato do estudo as enunciar pretende, essencialmente, dissecar em concreto, o objeto 
do estudo e de um modo mais particular perceber qual destas dimensões é atualmente mais usada e desenvolvida nos jovens portugueses.

\section{O CONSUMO DO MEDIA}

No atual panorama tecnológico encontram-se e descobrem-se novos métodos e formas de transmitir a sua mensagem aos cidadãos, seja através dos mass media (rádio, televisão imprensa, cinema) seja através da Internet. A convergência dos meios de comunicação e a difusão da informação atingiram no nosso tempo, múltiplas e variadas formas de oferecer produtos e serviços aos cidadãos. Fizeram também do "sujeito consumidor" um indivíduo capaz de tomar as suas próprias decisões de consumo e um virtual fornecedor de comunicação e informação. O "poder comunicativo" da Internet favorece essa permuta de serviços e faz do sujeito agente ativo dessa troca. Ele torna-se então mediador e mediado pela informação que o circunda. Este fato torna mais céleres as relações interpessoais dos indivíduos em sociedade. Todos estes fatores não seriam possíveis sem a inovação tecnológica dois meios de comunicação. Outros fatores como a "multiplicidade dos meios, vias de comunicação e os melhores e mais rápidos meios de transporte transformam num aparente paradoxo as características das sociedades modernas. A aproximação dos indivíduos e culturas fazem desvanecer diferenças, mas têm dado origem a uma multiplicidade de crenças e ideologias" (SANTOS, 2004, p. 25-26). Como fatores de motivação da participação dos espectadores podemos apontar os seguintes:

\footnotetext{
"Por um lado, existe a vontade de influenciar e participar enquanto cocriadores e/ou decisores sobre aspectos ligados ao conteúdo. Por outro lado, a vontade de exprimir a opinião e de ter visibilidade. Por outro, ainda, reside nas necessidades sociais dos indivíduos enquanto forma de socialização. Por último, a participação nos media é ainda motivada pela necessidade dos indivíduos, (nomeadamente dos jovens) em se fazerem ouvir, uma constante em todas as épocas, mas com maior mediatização desde o Maio de 1968. (...) Dar a sua opinião, poder fornecer o seu contributo, criar conteúdos, são práticas que, hoje em dia, se tornaram hábitos para determinados grupos sociais, no contexto de um clima de democracia global, onde não só cada um tem voz, como também dispõe dos meios para a difundir." (ARAÚJO, et al., 2009, p. 130)
} 
Deste modo, o modelo da comunicação mudou, e com ele mudou a centralidade dessa comunicação e a importância desse processo nas nossas vidas. Castells, na sua obra Internet of Galaxy (2001), começava por afirmar "A Internet é o tecido das nossas vidas”. Um olhar sobre a forma como hoje utilizamos a Internet talvez nos permita afirmar que "as nossas vidas são o tecido da Internet" (ESPANHA, 2009, p. 391). Segundo Santos atualmente:

\begin{abstract}
"Assistiu-se à passagem da sociedade dos produtores para a dos consumidores, através de um processo gradual de emancipação dos indivíduos, que deixaram de não ter escolhas. Transitou-se de um cenário de constrangimentos e de falta de liberdade para um panorama em que prevalece a autonomia individual. É a actividade do consumidor, e não do produtor, que se presume providenciar o interface essencial entre os indivíduos e a sociedade, uma vez que a vida dos actores sociais é determinada mais pela forma como consomem bens do que pela maneira como os produzem." (SANTOS, 2011, p. 7)
\end{abstract}

Perante este fato e segundo a mesma autora, a mudança de objeto, antes o produto para consumir determinava o sujeito, agora pelo contrário é o sujeito que determina o que quer consumir que faz o consumo ser

"encarado como uma instituição, ideologia ou mesmo como a religião do
século XX. De facto, os jovens cresceram numa sociedade em que o
consumo é uma forma de vida, encontrando-se, por isso, ambientados com a
cultura consumista. Assiste-se a uma propensão juvenil para práticas
consumistas, que surgem como uma alternativa de integração social, dada a
progressiva incapacidade em absorver este segmento nas estruturas
produtivas da sociedade. A erosão do trabalho, enquanto ocupação e fonte
identitária, conduziu a juventude a procurá-los no domínio do consumo."
(SANTOS C. F., 2011, p. 7-8)

Deste modo os modelos de consumo constituem a fonte pelo qual se regulam e organizam as relações e onde se conhecem e se reconhecem os indivíduos, os seus gostos e as suas apetências. No consumo também se podem conhecer os hábitos e os modelos éticos dos sujeitos. Para Santos "o consumo tornou-se na ocupação social juvenil favorita” (SANTOS, 2011, p. 8). Segundo a mesma autora, "se a juventude é uma fase em que a identidade se encontra em formação, uma vez que os jovens são envolvidos na procura do significado da sua existência, o consumo representa a principal área na qual os jovens jogam a relação entre estrutura e agência, enquanto negociam o seu papel e posição numa sociedade em constante mutação" (SANTOS, 2011, p. 8). 
O utilizador tem um novo e diferente papel. Não há parceiros silenciosos neste processo de mudança. As pessoas estão a adotar novos comportamentos baseados nas tecnologias disponibilizadas na Web 2.0 (redes sociais, blogues, tags, classificações, produção de conteúdos, partilha de vídeo e de preferências, fotografias on-line, etc.) (ESPANHA, 2009, p. 391-392). Nesse contexto torna-se desafiante contribuir para responder à questão: Qual é o papel dos media e da Internet na vida das pessoas? Importa, por isso, discutir questões de mobilidade, de conteúdos, de negócios, de redes, mas principalmente, é necessário falarmos de pessoas e de comunidades Como diria Espanha (2009, p.393), "O século XXI é das pessoas e da comunicação".

\section{Metodologia}

Como metodologia empírica utilizada no estudo aqui apresentado foram realizadas 3 sessões de Focus Groups (FG) com jovens entre os 18 e os 25 anos, todos eles estudantes universitários, a estudar na Universidade de Aveiro e de várias proveniências a nível nacional (continente e ilhas), num total de 21 de ambos os sexos. No que respeita a estrangeiros, apenas dois jovens de Erasmus ${ }^{6}$, oriundos de Espanha, Madrid e Santiago de Compostela, participaram na realização destes grupos de discussão e apenas uma única vez. As sessões foram todas realizadas no Departamento de Comunicação e Arte da Universidade de Aveiro durante o ano letivo 2010-2011, na sala do laboratório Sapo Campus. Os jovens participantes, tendo em consideração o critério de idade, foram convidados pessoalmente e por correio eletrônico. Foram feitos contatos com o Gabinete de Relações Internacionais da Universidade de Aveiro a fim de se identificarem estudantes estrangeiros, do programa Erasmus, para participarem nos grupos de discussão. Contudo, apenas portugueses e espanhóis estiveram envolvidos.

Podemos definir um grupo de discussão como "uma técnica de entrevista que reúne seis a doze participantes e um animador, no quadro de uma discussão estruturada sobre um assunto particular" (GEOFFRION, 2003, p. 319). Nestes FG observou-se uma pluralidade de

\footnotetext{
${ }^{6}$ O Programa Erasmus é um programa europeu que promove a mobilidade dos estudantes entre as instituições de ensino da Europa de modo a apoiar a criação de um Espaço Europeu do Ensino Superior . Para detalhes sobre o Programa Erasmus consultar: http://ec.europa.eu/education/lifelong-learning-programme/erasmus_en.htm
} 
opiniões que expressam a subjetividade e informação que cada indivíduo tem relação a um determinado tema. Neles consegue-se vislumbrar a imensa complexidade de conceitos e opiniões expressas, umas acreditando e assentes em convenções sociais mais ou menos aprovadas e aceites por todos, outras próprias do espírito livre que divaga e acompanha a imaginação. Nestes FG pudemos observar esta complexidade e diversidade de opiniões. O Focus Groups são pois grupos de trabalho coletivo onde ninguém tem uma resposta única, ou a mesma resposta às perguntas. É uma forma de aprimorar as questões. Todos têm uma ideia do tema ou da palavra a explorar. E é nesta diversidade que se encontrar a riqueza interpretativa para questões complexas. Esta é a finalidade dos grupos de discussão.

Com o uso do método de focus group (FG) procura-se, então, entender melhor o sentido das palavras, das noções e das respostas apresentadas pelos intervenientes. Não se pretende com os FG chegar a uma verdade, mas sim descobrir o que vai emergindo na discussão, o que se vai repetindo durante o debate. Encontrar esse "foco comum" é o objetivo final e primordial deste método de trabalho. Deste modo, o moderador do FG não é um elemento que condicione a discussão ou a limite impedindo a livre participação dos vários membros. Quando muito ele é o agregador de opiniões e o garante da "chama" que mantêm viva e acesa a "lâmpada" da discussão e do diálogo do grupo. Foi explicado aos jovens que eles não têm que concordar com uma definição, com uma ideia, dita ou referida pelos outros elementos, pois cada um deles pode ter uma ideia diferente e confrontando-a com as ideias dos outros, pode aprofundá-la e angariar novas ideias e patamares de reflexão. Em concreto nos FG realizados foram aprofundadas três temáticas essenciais que importa referir. A Juventude, a realidade da União Europeia (a emergência de uma consciência Europeia), o consumo dos media e a Web.

Os jovens que participaram neste projeto foram selecionados aleatoriamente e dentro da sua disponibilidade. Nunca os mesmos jovens participaram em mais que um grupo de discussão. Contudo, não se considera isso um problema dada a homogeneidade dos grupos quanto a idade, formação académica e diversidade de gênero. É claro que não é indiferente esses grupos terem constituição diversa, mas tem o lado enriquecedor de se poder ter maior número de intervenientes expressando o seu posicionamento sobre a problemática, que embora com enfoque diverso em cada um dos FG, era no fundo a mesma, a do contributo do consumo dos media para a emergência da consciência europeia nos jovens portugueses. 
Partindo daqui refira-se que na análise deste trabalho todos os grupos nunca tiveram menos de seis participantes, sendo que os animadores foram os alunos do $3^{\circ}$ ano da Licenciatura em Novas Tecnologia da Comunicação, da disciplina de Projeto com o tema: "Perceber qual é a influência do consumo dos media e bens culturais pelos jovens portugueses entre os 18 e os 25 na construção da consciência europeia", projeto esse articulado com a investigação para uma dissertação de mestrado. O projeto em questão assumiu a designação de "EURÁgora", dada pelo investigador, referindo-se à etimologia da palavra para significar o conteúdo do tema tratado. Deste modo o prefixo "EUR” refere-se à União Europeia e Ágora, palavra de origem grega, que significa praça pública, local de discussão. O nome EURÁgora queria significar isso mesmo - grupo de trabalho e discussão sobre temas relativos à União Europeia, neste caso em particular sobre o consumo dos media na formação da consciência europeia dos jovens portugueses. Refira-se ainda que este trabalho surge do projeto "L'émergence d' une conscience européenne chez les jeunes", iniciado em França e atualmente a ser desenvolvido em outros países da União Europeia. Estiveram também presentes nos FG, a Professora Lídia Oliveira e o Professor Vania Baldi. Refira-se que os três grupos de discussão versaram sempre temáticas diferentes, embora o objeto central do estudo fosse sempre o mesmo, ou seja, existiu no guião dos FG um corpo de questões comuns e um corpo de questões com foco específico, como se pode verificar no tratamento dos dados mais à frente. Refira-se ainda, que com a autorização dos jovens participantes, as três sessões foram gravadas em formato vídeo digital. A análise dos mesmos, foi realizada tendo como quadro heurístico as três dimensões da consciência. A referida análise foi realizada com o auxílio do software de análise qualitativa Nvivo, versão 8.0 para tratar os dados que a seguir se apresentam.

\section{RESUlTAdOS E DiscuSSÃo}

\section{A Juventude e a Consciência Europeia (Focus Group 1)}

Este FG que centrou a sua atenção no tema da juventude. Pode referir-se que existem muitos fatores a considerar no que se refere às características próprias desta fase etária. Notase uma grande indefinição de critérios. Os jovens não sabem definir os campos em que circulam. Não sabem o que "querem". Dizem, como que, "à guisa" de desculpa que ainda não sabem o que é o mundo dos adultos, porque ainda não estão lá em concreto. Mas depois 
dizem que sabem o que querem e o que desejam. Sabem, supõem, imaginam, mas de fato não entendem e não interiorizam essa sua condição. Talvez por falta de maturidade, talvez por falta de modelos de adultez que os ajudem a definir essa condição e que os ajudem a definirse. São jovens ainda imberbes que "tem sensações de viver" e oscilam entre o desejo de permanecerem jovens e de serem adultos. Fogem e saltam de uma condição para outra (da condição adulta e juvenil), por falta de coerência, muito por aquilo que a sociedade lhes exige e lhes propõe.

\section{Gráfico 1-Qualidades da Consciência no FG1_Juventude}

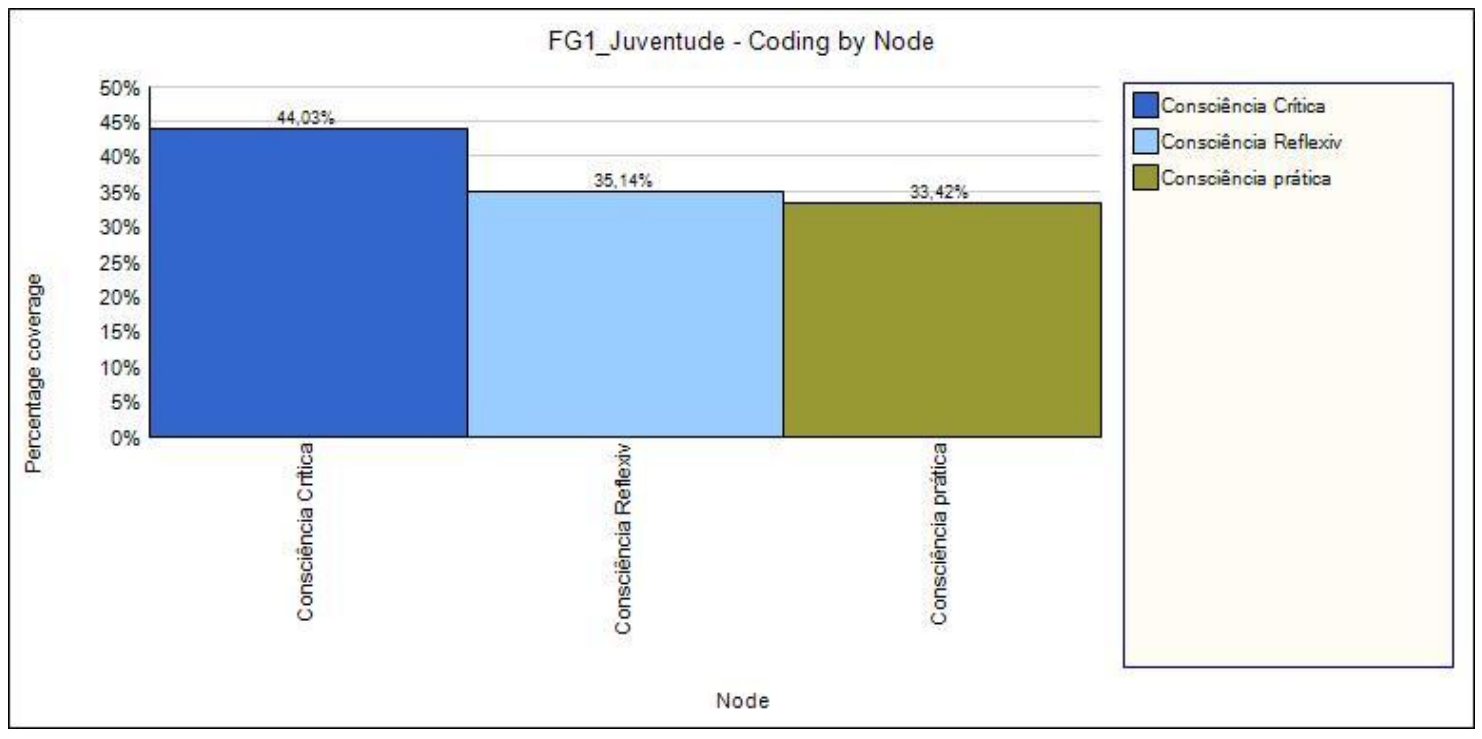

Observa-se, ainda, que os jovens têm consciência de si. Este fato é aprofundado quando da comparação do estado juvenil em que se encontram com o estado de adultez. Têm consciência do estado de ser adulto pelo que visualizam e percebem do mundo dos adultos, seja pelo ambiente familiar de onde provêm seja pela realidade social que observam e exploram.

Segundo a análise de dados colhidos através da análise qualitativa e relativamente às qualidades da consciência indicadas, os jovens neste FG têm uma maior consciência crítica e reflexiva em relação à consciência prática (Gráfico 1). Isto demonstra o sentido crítico que os jovens têm em relação ao que vivem, ao que sentem e experimentam. A consciência reflexiva acompanha a tendência nesta fase etária, no entanto, no que se refere a tomadas de posição e levar os jovens a agir, nota-se um défice em relação aos outros parâmetros. Se compararmos o 
índice de referências da consciência crítica nos outros grupos de discussão, observa-se que em todos esta qualidade da consciência é aquela que é mais assinalada, seguindo-se a consciência reflexiva neste FG e no FG $3^{7}$ (os Media e Web) e só no FG $2^{8}$ que aborda as questões da União Europeia constatamos que a consciência prática surge em segundo lugar. Observa-se ainda neste grupo de discussão a dualidade de critérios. Esta é uma nota marcante neste estádio de vida dos jovens. O querer e o não querer surgem quase sucessivos. Se por um lado desejam a independência, não querem ser dependentes de nada, embora tenham consciência que terão de depender de fatores sociais, como trabalho, emprego, para se autonomizarem. Querem ter boas condições econômicas, para poderem sustentar as suas necessidades, mas não querem ficar eternamente dependentes de um trabalho ou da obrigação de ter que pagar a prestação da casa ou do carro. Perante esta condição sentem-se coagidos a adiar em muitos dos casos a saída da esfera familiar, como baluarte de uma situação cômoda e prática para experimentarem ao máximo novas e variadas experiências de vida. Referem o fato de quererem constituir uma família, por recondução da tradição familiar, no entanto, "incomodaos" o fato de virem a ter pessoas que dependam deles na sua vida, pois dizem-se privados da sua individualidade e liberdade. Referem as responsabilidades e as preocupações como críticas negativas ao estado de adultez e chegam a referir que este estado lhes trará alguma tristeza e em alguns casos pouca alegria em usufruir da vida, pois enquanto jovens sentem-se otimistas, despreocupados e com tempo para fazer tudo o que sonham. Sabem exatamente o que querem para serem felizes.

A tônica dominante é um nem sim nem não (o que poderíamos definir como "nim", ou mais ou menos) parece ser aquilo ou aquela característica que melhor os define. Referem o desejo de que querem ser felizes e viverem o máximo possível. Não têm um projeto de felicidade, mas sabem o que têm fazer para não serem infelizes e esta passa por ter estabilidade econômica e emocional. $\mathrm{O}$ fato de saber exatamente o que querem, se têm um projeto de vida, uma perspectiva temporal de futuro, isso ainda é uma miragem. Esse fato leva-os a considerarem como uma boa hipótese a circunstância de ficarem durante mais algum tempo como "não adultos".

\footnotetext{
${ }^{7}$ Ver gráfico 2

${ }^{8}$ Ver gráfico 3
}

$$
\text { ANIMUS } \begin{aligned}
& \text { Revista Interamericana de Comunicação Midiática } \\
& \text { E-IssN 2175-4977 | v.11 n.22 | } 2012 \text { | www.ufsm.br/animus }
\end{aligned}
$$


Não se pretende com esta análise qualitativa encontrar "culpados" para o estado em que se encontra a condição juvenil, ou dizer que os jovens são os causadores do seu próprio estado. Quando muito se pretende descrever fatores que condicionam os jovens a tomar algumas decisões e a protelar os seus projetos de vida. Pode, também, referir-se que vivem numa sociedade que é capaz de criar expectativas aliciantes aos jovens, quando ainda estudantes, propondo uma excessiva lista de cursos universitários e com "saídas" bem remunerados, realidade que por vezes é gorada, pois não existem na prática condições e capacidade dos empregadores para "absorver" todos os recém-licenciados. Uma questão cultural que aqui também podíamos aduzir, prende-se com uma questão cultural do nosso país. Em Portugal os jovens são educados para um determinado fim na sua vida acadêmica. Tirar um curso não é sinônimo de ter mais cultura e de possuir "armas" para se saber posicionar perante a sociedade como ser pensante e atuante. Tirar o curso tem, em Portugal, uma única finalidade - ter um bom ordenado e um "grande" emprego. Vemos que em outros países do mundo esta questão cultural é mais esbatida e em muitos casos os jovens que terminam a sua caminhada acadêmica, têm um trabalho diferente daquele que trilharam na sua educação acadêmica. Em alguns casos, muitos jovens empreendem a sua atividade profissional em ramos tão distintos como a agricultura, a prestação serviços, ou outros fora da sua área de formação. Será que falta aos nossos jovens portugueses a humildade necessária para antecipar as ocasiões que a vida e as oportunidades que o mercado de trabalho lhes oferece? Podem pensar que ao sair da universidade tem logo colocação numa empresa multinacional, quando de fato aquilo que acontece é que muitos impedidos pelo escasso leque de colocações, se vêm obrigados a tirar mais um curso e a continuar a adiar a sua emancipação social. Poder-se-ia referir que o fato de encontrar trabalho e exercer uma atividade profissional, independente da sua área de estudos, é quase como que um "rito de passagem", nos dias que correm, para o jovem ser considerado adulto, por si e pela sociedade.

Em resumo o moderador refere que existe uma grande ambivalência nas proposições apresentadas pelos jovens no presente FG sobre a condição juvenil: a condição juvenil leva consigo uma vertigem para o desconhecido que está pela frente, mas este desconhecido resulta apavorante uma vez que não apresenta garantias: portanto o desconhecido é uma aventura que não se quer vivenciar diretamente mas com uma escolha que a torne doméstica, 
cómoda e confortável, ao passo que os adultos são aqueles que são mais independentes, mas que se tornam mais dependentes (com tristeza).

Relativamente à questão da identidade do jovem português e à questão que lhes foi colocada: “És mesmo português?", os jovens no geral estão bastante animados em referir que têm muitas expectativas para perspectivar o seu futuro em Portugal. Realçam aspectos de "luta", de "coragem", de " excelência organizacional" e sobretudo de saber enfrentar as situações críticas, com habilidade. Vários jovens referiram mesmo que uma característica do português é saber "desenrascar-se". Os jovens portugueses têm orgulho no próprio país e para com a sua própria identidade cultural. Referem que os portugueses são acolhedores, hospitaleiros e divertidos. Os jovens observam alguma confiança nos portugueses, mas pouca nos movimentos socialmente organizados, como por exemplo no movimento "Geração à Rasca".

Outro aspecto digno de nota foi perceber que existem algumas razões para ficar em Portugal, contudo, a quase maioria é a favor da emigração para um país da Europa. Referiram que para viajar para fora ou emigrar é preciso ter dinheiro. O ir para o "estrangeiro" é pensado como um lugar convidativo, tendo em conta uma perspectiva temporal de futuro, sendo esta vista como espaço definitivo, a curto ou longo prazo, para residir e trabalhar. No entanto, nota-se alguma dificuldade dos jovens em se projetarem para fora do país, a qual se pode interligar à condição de apego/dependência à família. Os pais e o país sobrepõem-se simbolicamente? Viajar para o estrangeiro significa afastar-se da família, mas também é uma forma de ter melhores condições materiais/econômicas. Portugal é um país pobre. Pelo que parece existir aqui uma "raiz" reconhecida por todos, da dificuldade em pensarem num projeto de vida em Portugal.

É importante referir, ainda, que os jovens participantes transmitiram a ideia de que eles não fazem uso das tecnologias, regra geral, para partilhar experiências e conhecimentos, conseguir ocasiões de formação ou para autopromover as próprias capacidades. Os jovens portugueses não usam os canais disponibilizados pela Web para travarem conhecimento com outros jovens que vivem no estrangeiro. Dizem que Portugal não é um país "fechado", mas não experimentam a mobilidade. A principal razão apontada para não viajarem foi a econômica. 


\section{A União Europa e consciência europeia dos jovens Portugueses (Focus Group 2)}

Deste Focus Group conclui-se que os jovens são na sua maioria, descrentes quanto ao Projeto Europeu. Vêm as vantagens práticas em ser europeu, como a mobilidade, a livre circulação de pessoas e bens, a moeda, mas são "egoístas" no que se refere ao partilhar um espaço comum europeu, uma cultura comum, modos e leis de políticas comuns entre os vários países que compõem a União Europeia. Referem-se negativamente à União Europeia comparando-a como a criação de um "novo império" muito à semelhança dos anteriores impérios europeus. Dizem que se anteriormente não resultou, agora também não irá resultar. Nota-se uma consciência bastante crítica sobre as várias realidades europeias, sejam elas de índole econômica, política e social. Observa-se ainda pela análise do gráfico 2 que os jovens refletem pouco sobre a realidade da União Europeia, no entanto como se pode observar são bastante críticos e assumem algumas posições de confronto. Muitos dizem-se indiferentes ao projeto Europeu quando questionados sobre assuntos de política europeia, geografia e cultura.

\section{Gráfico 2 - Qualidades da Consciência no FG2_ Realidade Europeia}

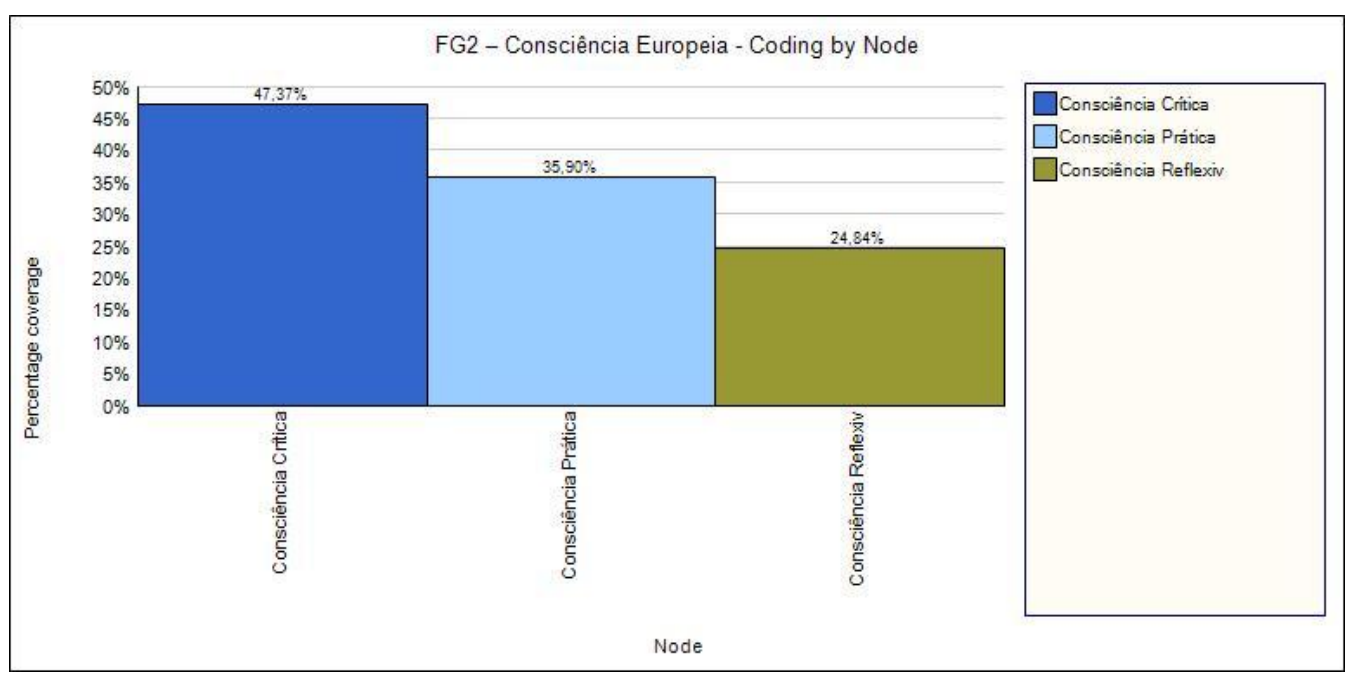

Os jovens portugueses participantes neste FG referem também as diferenças culturais dos diversos países como um aspecto a considerar na aproximação e na comunicação entre os mesmos. Referem que a língua inglesa é aquela que melhor está adaptada para ser utilizada como ferramenta de comunicação entre os vários países, porque já existe e porque é a mais falada em todo o mundo. Por isso, dizem não ser necessário criar uma nova língua para colmatar esta hipotética falta de comunicação entre as diferentes culturas. Dizem ainda que os 
europeus nascem de uma raiz comum, de um tronco comum que é a cultura greco-romana e este fato deve ser por si só valorizado, tanto numa perspectiva dialética entre as diferentes culturas, como entre os vários povos, que daí são oriundos. Os jovens portugueses admiram os seus antecessores, devido à coragem que tiveram em partir para "descobrir e dar novos mundos ao Mundo". Dizem-se entender as limitações culturais do povo português, mas enaltecem as suas qualidades e capacidades em se adaptarem a novas e diferentes realidades. Referem casos de sucesso de portugueses tanto na área do conhecimento científico, como político e cultural. Fazem, ainda referência, aos grandes jogadores de futebol que Portugal deu e continua a dar a este desporto.

Sobre a questão de saber se os jovens portugueses têm ou não uma consciência europeia, podemos dizer que têm conhecimento e consciência de algumas realidades existentes na União Europeia. No entanto, se perguntamos aos jovens se se sentem europeus e se essa consciência europeia os faz sentirem-se mais europeus, dizem que não, porque são mais os fatores que os afastam do que aqueles que os aproximam. Têm unicamente aquilo que poderíamos apelidar de uma consciência prática, isto é, uma sensibilidade prática perante a realidade da União Europeia, onde a moeda, a mobilidade, a troca de produtos e a livre circulação de pessoas são os fatores mais referenciados. O tema da pertença de Portugal à União Europeia foi um dos temas que gerou maior discussão, no entanto, disseram que fazer parte da UE traz alguns benefícios e algumas vantagens ao nosso país, concretamente agora e devido à conjuntura econômica global pela qual atravessamos. Os jovens disseram ainda que o tema da Europa e da União Europeia não é um aspecto muito valorizado na escola e na sua formação formal.

\section{Os Media e a Web na formação da Consciência Europeia (Focus Group 3)}

Como síntese do FG3 pode afirmar-se que a maioria dos jovens presentes nesta sessão do Focus Groups são da opinião que os media e os bens culturais promovem a formação de uma consciência europeia, ao passo que dois jovens referem que aquilo que faz com que as pessoas se sintam europeias é a questão de se utilizar a mesma moeda. Segundo os dados obtidos pelo software de análise qualitativa observa-se que os jovens participantes neste grupo de discussão tem uma maior consciência crítica sobre o modo como vêm os media e o 
consumo que fazem dos mesmos. Verifica-se também que a consciência reflexiva vem em segundo lugar, seguida da consciência prática. Isto leva-nos a observar que os jovens pensam e questionam algumas realidades dos media e da web, em concreto no que se refere aos bens culturais produzidos na Europa e na América e sobre o consumo dos mesmos. Vê-se que relativamente à consciência prática os jovens presentes neste FG não assumem uma posição frontal sobre as escolhas que assumem ser as melhores. Pode dizer-se que são "arrastados" pelos media para consumir "media", isto é, pela publicidade e pela distribuição que é feita pelos media, os jovens consomem mais bens culturais provenientes da América que os bens culturais (cinema, televisão, música) da União Europeia.

\section{Gráfico 3 - Qualidades da Consciência no FG 3 - Os media e a web}

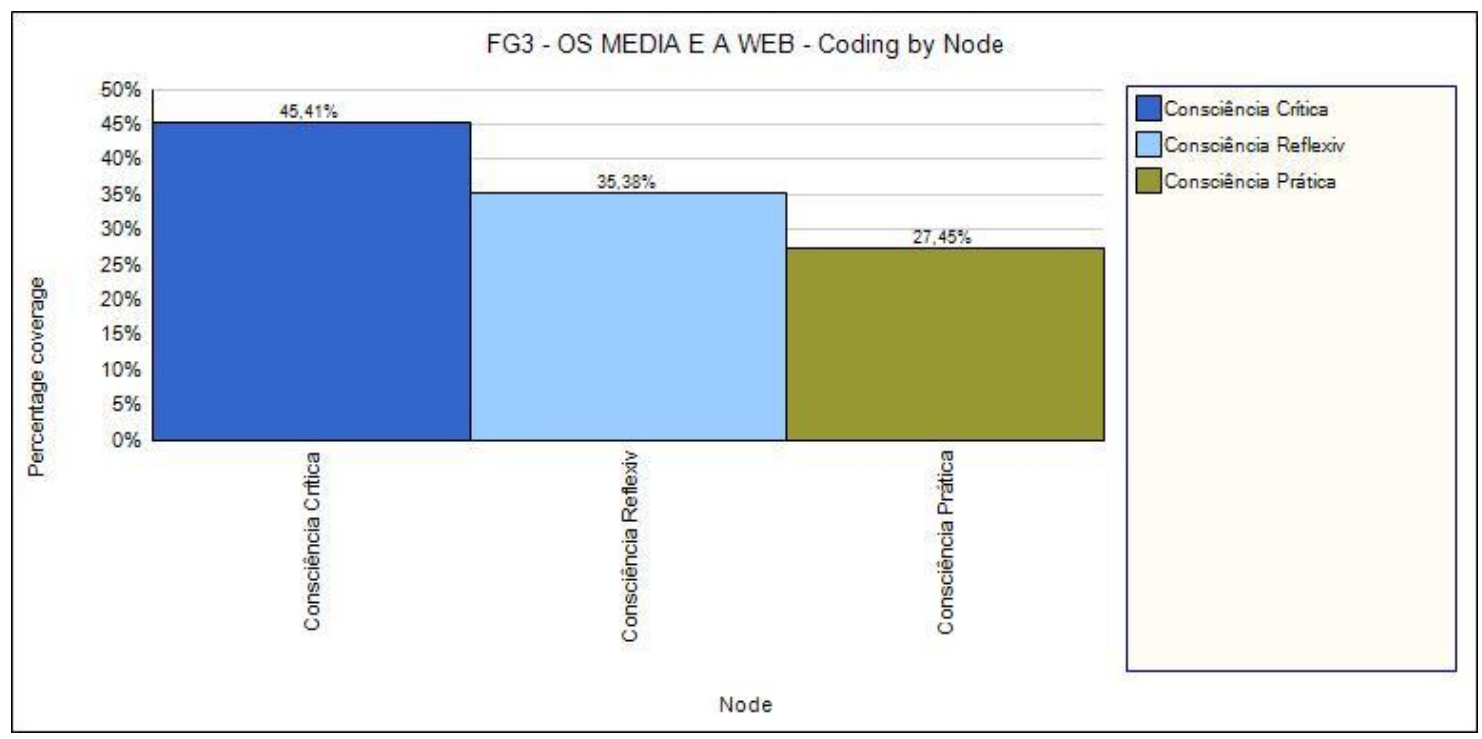

Importa ainda dizer que este FG foi essencial para entender aquilo que de fato é a questão de investigação, isto é, se de fato o consumo dos media e o dos bens culturais são os principais promotores e potenciadores, para a formação de uma consciência europeia dos jovens portugueses. Pode dizer-se que sim, pela análise que foi obtida dos vários participantes. Apesar das dúvidas suscitadas ao longo da reflexão e onde foi dada primazia aos media (cinema e televisão) como meios fulcrais na formação de uma opinião pública, os jovens foram comparando os bens culturais produzidos na Europa e em Portugal, com aqueles que nos são “oferecidos” pelos Estados Unidos da América. Aqui foram todos unânimes em frisar que os bens culturais europeus são melhores na qualidade cultural que apresentam, isto 
é, nos conteúdos culturais que transmitem, ao passo que os bens americanos são melhores pelas condições técnicas utilizadas na produção. Referem o grande potencial da América em produzir grandes obras cinematográficas e de serem um "império" econômico da $7^{\mathrm{a}}$ arte. Referem ainda a grande máquina de distribuição e propaganda que têm na divulgação dos seus produtos e bens culturais, até porque se formos a analisar o que os jovens referenciaram como bens culturais norte americanos apenas ocupa lugar de destaque o cinema, o mesmo não acontece com a literatura, a música e outras formas de produção cultural, em que dizem a Europa ser superior à América. Para contrariar a tendência do mercado foi referido pelos jovens que a Europa deveria apostar mais na exportação dos nossos produtos culturais, pois desta forma seriam mais conhecidos e divulgados.

Relativamente ao que se entende por bem cultural os jovens, todos foram unânimes em dizer que os bens culturais podem ser físicos, isto é, podem ser vistos (objetos palpáveis) assim como são também bens imateriais. Todos eles são na opinião dos jovens, bens universais, na medida em que não pertencem a um único povo, mas fazem parte da herança cultural dos povos. Esta percepção, referem, vêm dos media e da sua atuação na sociedade. Este "poder de difusão e divulgação", que os media têm no consumo, é devido ao uso que as novas tecnologias da informação têm e que tornam esses bens mais fáceis e acessíveis de “consumir", independentemente do seu país de origem. Ainda dentro deste ponto refira-se a opinião do jovem espanhol que disse que o mais importante, não é a qualidade dos bens culturais, mas sim a distribuição. Nós consumimos o que temos. Se não tivermos não consumimos, e esta é a verdade. É o que decide a escolha entre o cinema americano e o cinema europeu. A distribuição é tudo. Importa também referir que os jovens consideram que os bens culturais deveriam ser "materializados" em suporte digital, para que assim o acesso seja livre e possam ser acedidos por todos os indivíduos, possibilitando o seu uso e consumo em maior escala. Não deixa de ser curioso o que foi apontado pelos jovens quando referiram que para ver um filme europeu se tem que ir a festivais internacionais de cinema, pois encontrar um filme europeu numa sala de cinema portuguesa é ainda uma "utopia". Referem que é pela divulgação e propaganda que uns bens culturais são mais conhecidos, comparando os bens produzidos na Europa com aqueles que são feitos noutras partes do mundo. Ainda sobre a reflexão acerca do que é um bem cultural sublinha-se a importância que o jovem estudante de Erasmus refere ao dizer que "o bem cultural mais importante é a 
atitude de uma pessoa perante a vida e a forma como a pessoa se relaciona com os outros". Este fato, no entendimento do jovem marca um país e uma cultura e a língua é o reflexo dessa realidade. Este jovem faz uma crítica, dizendo que "ser europeu não é ser Francês, Alemão, Austríaco. Ser europeu é ser Espanhol, Português, Italiano, Grego, Cipriota. Muitas vezes achamos que ser europeu é ser alemão. A ideia de Europa é tudo, não é só um país, não é só Alemanha". Assumir esta consciência europeia, como globalidade de todos os países e culturas e não só de um país, seja ele mais forte economicamente ou maior a nível territorial pode ser um indicador para o surgimento de uma consciência europeia, nos jovens. $\mathrm{O}$ fato de se pertencer a uma unidade política e econômica (EU) não deverá ser a única razão para os jovens se considerarem Europeus. Os valores humanos emanados das várias culturas europeias são prova e fundamento para um jovem dizer que "a ideia de Europa é tudo, não é só um país", ou uma moeda, um hino ou uma bandeira. Esses símbolos meta nacionais são os meios que alavancam e materializam essa forma de ser união na Europa, de ser União Europa.

Sobre o conhecimento que os jovens têm dos bens culturais produzidos na Europa observou-se um grande desconhecimento, apenas sendo referidos algumas, poucas, obras de autores Europeus em áreas como a literatura, música e até mesmo no cinema. Por causa da língua inglesa muitos jovens sentiram dificuldade em fazer distinção entre grupos musicais Europeus e Americanos (caso dos Coolplay, entre outros, que pensavam ser americanos).

Os jovens referiram que vão buscar referências aos media para se dizerem europeus, pois dizem que os media são os principais mediadores, vinculadores da opinião pública. A televisão, o cinema e a internet conseguem transformar um bem cultural, numa coisa boa, como numa coisa menos boa. Dizem também que é a cultura que nos identifica como europeus, assim como o testemunho de vida que observamos pelos familiares e amigos emigrados.

No que respeita ao papel dos media na formação da opinião pública e o modo/consumo que os Jovens fazem deles, referiu-se que é muito importante comparar notícias e fatos entre os diversos media, para se ter a percepção correta do fato noticioso anunciado. Fazer comparação entre canais informativos de televisão, jornais on-line e rádios é importante, mas mais importante ainda é comparar o que veem na televisão com o que leem nos jornais on-line e ouvem nas rádios. Essa síntese assume-se prioritária para os jovens conhecerem em profundidade a realidade dos fatos e não apenas o que alguns media querem transmitir, como 
sendo o mais factual e verídico. A manipulação informativa foi referida pelos jovens e a solução para a combater passa por fazer a filtragem desses conteúdos pelos vários media. Referiram que a formação acadêmica também os prepara para possuírem uma consciência mais crítica em relação aos que os media referem como verdades. Apontam o exemplo dos pais, para dizerem que por não terem desenvolvido esta sensibilidade estão mais expostos a serem influenciados pelos media.

Sobre a Questão da Web e das redes sociais e ao fato destas potenciarem o conhecimento que se têm da União Europeia pelos "amigos estrangeiros" que se fazem pela rede, os jovens referiram que têm muito poucos "amigos on-line" estrangeiros, que no essencial os seus amigos nas redes sociais são pessoas com quem têm conhecimento presencial. Apenas um jovem referiu que tinha no Facebook alguns familiares e amigos que estão ou são estrangeiros, mas que os conheceu antes de entrar nessa rede social. Disseram que as redes sociais facilitam o conhecimento, mas são perigosas. Referem que deve existir uma apresentação "física" anterior, para que essa amizade seja de fato reconhecida. Isto levanta uma questão que é aquela que se refere à identidade dos jovens nos ambientes digitais. Para combater as falsas presenças na rede os jovens referem que deve existir um conhecimento prévio da pessoa, isto é, o internauta, precisa de ver e comunicar com a pessoa em ambiente não virtual para que a possa aceitar como "amiga", no espaço virtual.

\section{SÍNTESE QUALITATIVA DOS FOCUS GROUPS}

Através da análise qualitativa realizada dos vários grupos de discussão pode aferir-se as seguintes conclusões.

Os jovens têm uma maior apetência para desenvolverem nesta fase etária a chamada consciência crítica. Segundo dados observados no gráfico 4, em todos os FG realizados esta é a qualidade da consciência mais revelada. 


\section{Gráfico 4 - Jovens e qualidades da consciência nos vários FG analisados}

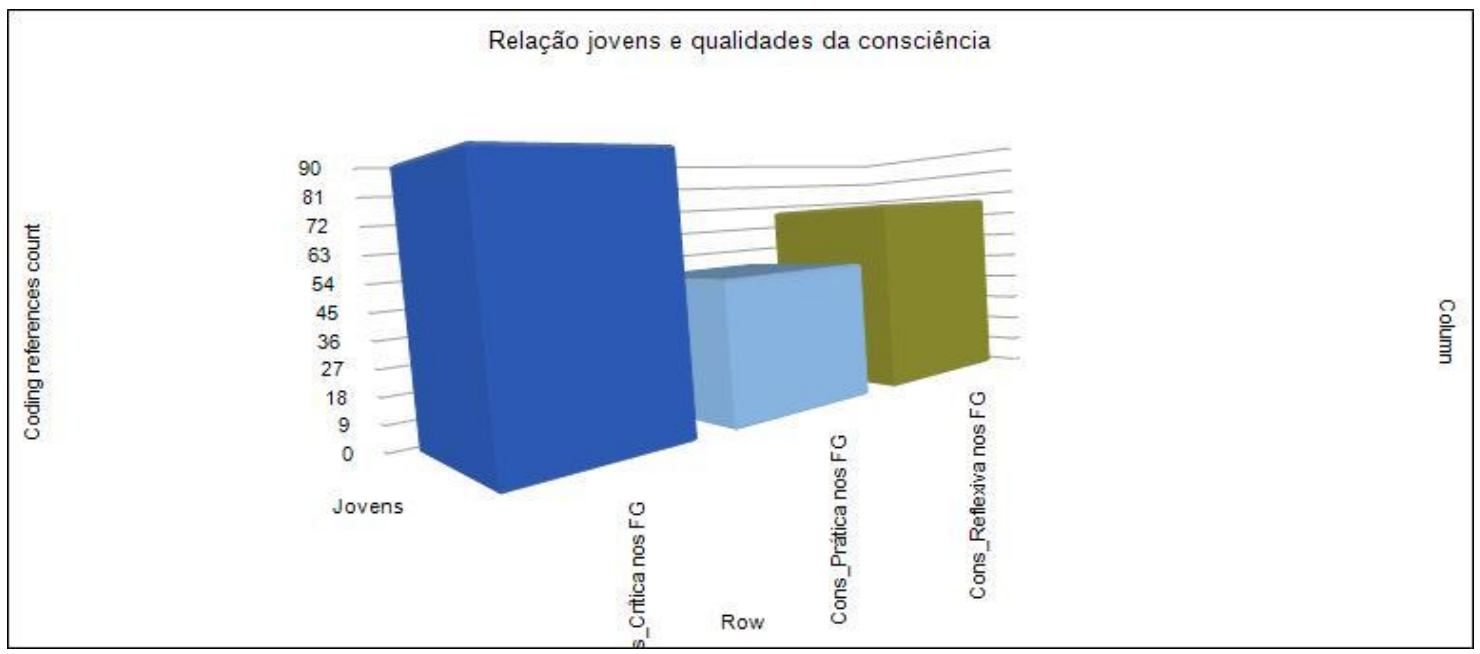

Este fato é importante para se entender o modo como os jovens abordam a realidade. A crítica que tecem aos problemas sociais em que se encontram inseridos, são reflexo desta sua tomada de posição perante a vida. Pode dizer-se que refletem menos do que criticam e agem menos do que pensam. Pode concluir-se que os jovens não tomam posição perante a vida? $\mathrm{O}$ fato de adiarem decisões importantes parte deste aspecto cognitivo? Estarão os jovens "cansados" e desiludidos com a atual situação da sociedade portuguesa? Será por isso que criticam tudo e todos, embora não tenham uma opinião bem formulada sobre os assuntos e na prática não ajam de acordo com aquilo que dizem criticar/discordar/aceitar?

Nesta reflexão não se pretende generalizar. Pretende-se sim chamar a atenção para este fato e para as consequências que a realidade social, política e econômica têm na vida dos jovens portugueses.

Pelo que foi possível observar nos FG e pela análise qualitativa facultada pelo software enunciado, foram ainda codificadas as várias referências às qualidades da consciência conforme os vários grupos de trabalho. 


\section{Gráfico 5 - Qualidades consciência vs FG}

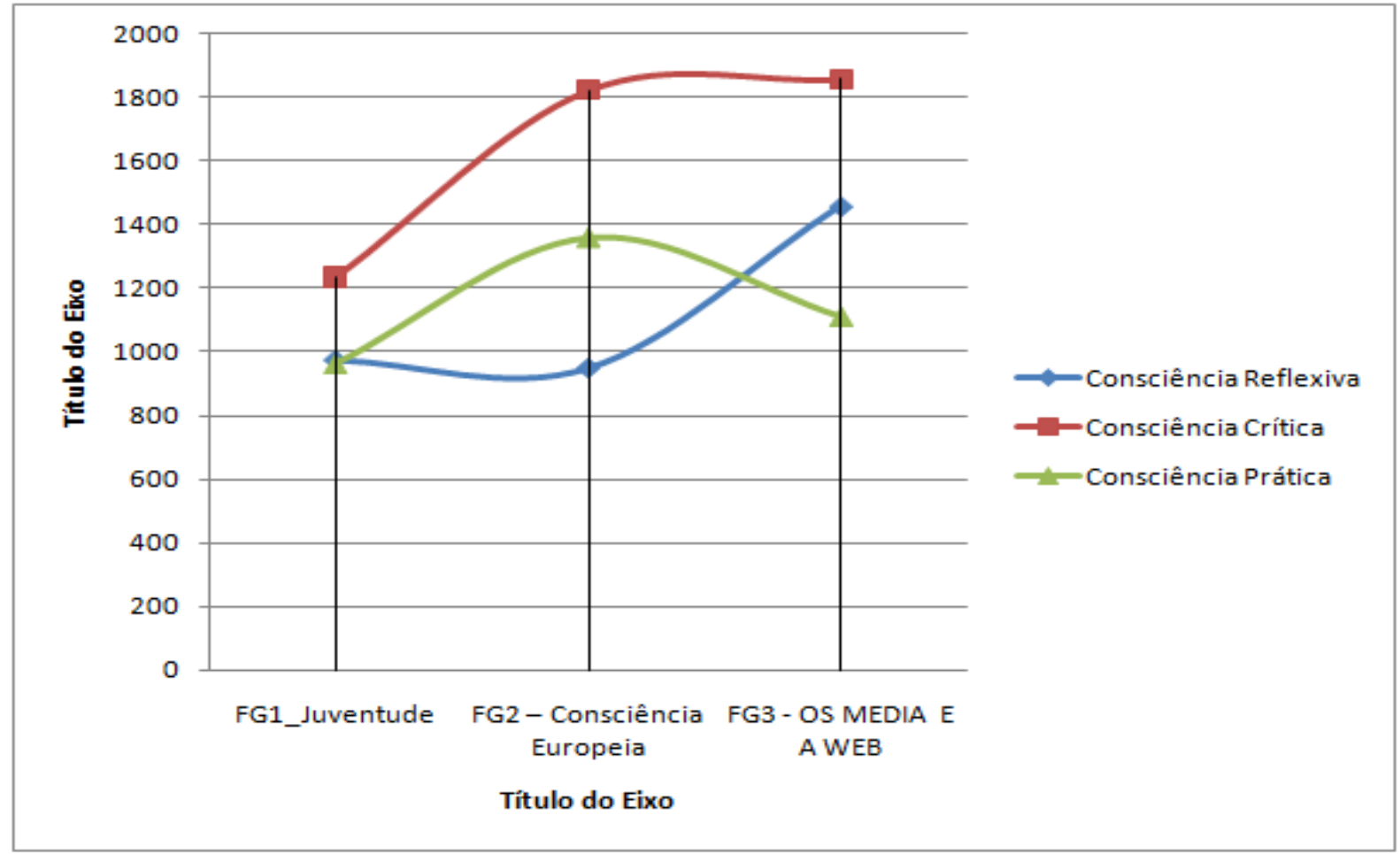

No gráfico 5 pode observar-se que a consciência crítica é aquela que apresenta uma maior relevância face às outras qualidades da consciência. No entanto, é também possível observar que a consciência reflexiva tem aproximadamente o mesmo valor que a consciência prática no FG1, no entanto a mesma desce alguns pontos no FG 2 quando se reflete sobre a realidade europeia e sobe significativamente no FG 3 (media e web). O inverso sucede com a consciência prática. De modo geral pode dizer-se, então pela análise dos dados, que os jovens refletem menos sobre a realidade europeia do que sobre os media e a web. Apesar de serem diferentes jovens nos vários FG o que se verifica é que todos têm um cotidiano em que os media ocupam uma presença muito forte nas suas rotinas cognitivas e sociais, o que faz com que tenham facilidade em se expressarem e analisarem este tema. O consumo dos media e da web é mais reflexivo e seletivo por parte dos jovens, ou seja, os mesmos quando consomem um determinado bem cultural refletem sobre as qualidades e proveniência dos mesmos, embora como vimos anteriormente este fato muitas vezes seja viciado face ao papel da distribuição e da publicidade que alguns bens culturais são objeto. Relativamente à consciência prática a mesma é assumida pelos jovens no que se referem às questões de identidade europeia com maior força e convicção. Os jovens agem consoante o que 
interiorizam e esse fato leva-os a tomar partido ora favorável a uma aceitação de uma consciência europeia, ora ao contrário. Da reflexão do grupo de discussão FG 2 sobre a União Europeia, os jovens são bastante mais práticos isto é, vêm mais aquilo que é utilizável e consumível no que se refere aos benefícios que oferece a pertença à União Europeia (moeda, mobilidade, isenção de taxas, fronteiras livres, entre outros) do que pelo ideário do projeto europeu em si. Isto talvez se fique a dever ao fato de as coisas práticas serem sentidas nas rotinas cotidianas, enquanto que a reflexão ideológica está afastada do quotidiano estando até muito pouco presente na formação formal/escolar dos jovens. Este deveria ser um ponto a considerar pelos decisores europeus, ou seja, em que medida nos currículos dos jovens dos países europeus deveria ser obrigatória a aprendizagem de tópicos fundamentais para compreender a Europa enquanto realidade histórica e cultural, para além de realidade geográfica e política.

\section{Gráfico 6 - Volume de trabalho referenciado em cada FG}

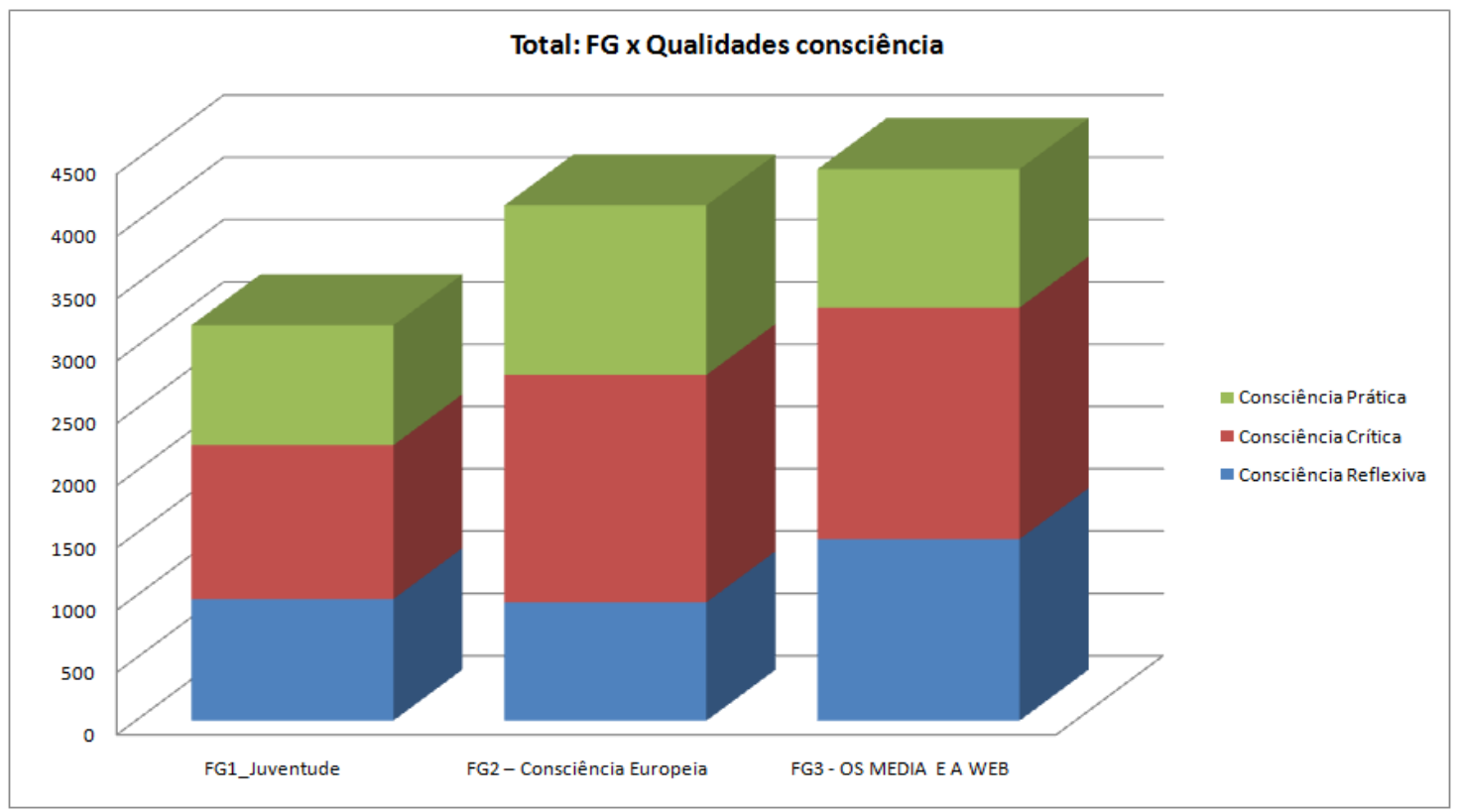

Outro aspecto que se pode observar é que dos três Focus Groups realizados, aquele que apresenta maior volume de referências foi o FG3 que versou o tema dos media e da web. Desta observação pode deduzir-se que os jovens sentem mais afinidade em tratar assuntos relativos aos media e à web que em relação aos outros temas. De todos os FG realizados notase que aquele que menos produtividade alcançou foi o referente à juventude. Será porque os 
jovens não se sentem à vontade para falar deles mesmo? Ou será que não sentem necessidade de o fazer? Será para eles a juventude um problema? Ou será apenas uma fase de transição, um estádio de vida que não importa dar muita importância?

Sobre o FG que versou a União Europeia os jovens presentes demonstraram também um bom volume de trabalho que se pautou essencialmente pelo modo como o grupo moderador e os professores foram colocando as questões. Nunca condicionaram o diálogo, pelo contrário, face a momento de menos entusiasmo na discussão, aparecia uma pergunta acutilante que os despertava para a reflexão e para o debate.

\section{CONSIDERAÇÕES}

Para terminar refira-se que de modo geral todos os jovens que participaram nos FG apresentam as várias qualidades da consciência no seu discurso, em alguns casos mais reflexiva, noutros, mais crítica ou prática.

Pode dizer-se, também, que os jovens têm consciência de si pelo que foi analisado no FG 1 sobre a juventude e dos problemas que os atingem. Têm conhecimento dos outros e da realidade circundante, do mundo, pelo que observam e consomem dos media, da web e dos bens culturais, e questionam-se parcialmente como consumidores ou simples utilizadores destes mesmos media assim como expressam muitas suspeitas sobre a sua neutralidade e transparência. Os media são a fonte fundamental a partir da qual os jovens formam a sua consciência europeia. Esta fonte é tanto mais importante quanto a Europa é pouco abordada de forma sistemática na formação escolar dos jovens portugueses, ou seja, não existe nenhuma disciplina com esta finalidade específica.

Os jovens têm, enfim, consciência da sua globalidade e territorialidade europeia. Neste ponto pode dizer-se que os jovens têm em si "espaço" para fazer crescer e deixar crescer o "gérmen" da consciência europeia. Comparando os jovens com a Consciência Europeia pode dizer-se que estão em contínua formação e maturação. Ambos continuam a procurar expressões de existência. Ambos querem ser mais que parecer. Os jovens são o futuro da humanidade, usa-se dizer. Pode dizer-se que o futuro da Consciência Europeia, do projeto europeu está nas mãos dos jovens pois deles depende o terminar da "metamorfose" de que 
falava metaforicamente Edgar Morin (1988), quando dizia que a Europa é um projeto comum, um caminho comum, uma "comunidade de destino".

\section{REFERÊNCIAS}

ARAÚJO, V. et al. Espectadores e participantes: da questão sociológica à questão económica. In: GUSTAVO, C., ESPANHA RITA, ARAÚJO, VERA (Ed.). Da comunicação de massa, à comunicação em rede. Porto Editora. Porto, v.18, 2009. cap. IV, p.272. (Os Produtores: Jornalistas e Utilizadores).

CORETH, E. O que é o Homem? Verbo Editora. Lisboa: Verbo, 1986. 261.

CRISTINA, P. A. et al. Protesto Geração à Rasca juntou entre 160 e 280 mil pessoas só em Lisboa e Porto. Público 2011.

CRUZ, M. B. D. et al. A condição social da juventude portuguesa: ICS - Instituto de Ciências Sociais da Universidade de Lisboa: 285-307 p. 1984.

ESPANHA, R. O século XXI é das pessoas e da comunicação (tal como o século XX foi das empresas e do Estado). In: CARDOSO, G., CÁDIMA, FRANCISCO RUI, CARDOSO, LUÍS LANDERSET (Ed.). Media, Redes e Comunicação - Futuros Presentes. Obercom \& Quimera, 2009. p.399.

EUROPEIA, C. CARTA DOS DIREITOS FUNDAMENTAIS DA UNIÃO EUROPEIA (2000/C 364/01): Jornal Oficial das Comunidades Europeias: 22 p. 2000.

Consciência europeia e totalitarismo - Resolução do Parlamento Europeu, de 2 de Abril de 2009, sobre a consciência europeia e o totalitarismo: Jornal Oficial da União Europeia: 3 p. 2009.

Eurobarómetro Flash sobre «Juventude em Movimento»: Press Realease Rapid MEMO/11/292. Bruxelas: 7 p. 2011.

EUROPEIA, C. D. C. LIVRO BRANCO DA COMISSÃO EUROPEIA: UM NOVO IMPULSO À JUVENTUDE EUROPEIA. Bruxelas 2001.

GEOFFRION, P. Investigação Social. Da problemática à colheita de dados. $\underline{\mathrm{O} \text { grupo de }}$ discussão. Loures: Benoît Gauthier (Dir.). 13: 319-343 p. 2003.

HACK, C.; PIRES, G. D. L. Lazer e mídia em culturas juvenis: uma abordagem da vida cotidiana: 12 p. 2005.

INTERNATIONAL, V. B. S. Youth No Longer Defined by Chronological Age; Consumers Stay 'Younger' Longer 2008. 
MORIN, E. Pensar a Europa. Publicações Europa-América. Men Martins: 1988. 170.

ONU, A.-G. D. N. U. A/RES/50/81 Programa Mundial de Acção para a Juventude do Ano 2000 e além: 28 p. 1995

PEREIRA, A. C. Jovens portugueses querem emprego: Presseurop: 2 p. 2010.

PEREIRA, C. D. S. O conceito de "juventude" na Publicidade: modernidade, felicidade, sociabilidade, amizade e liberdade.: Intercom - Sociedade Brasileira de Estudos Interdisciplinares da Comunicação - XXXII Congresso Brasileiro de Ciências da Comunicação. 7: 35-54 p. 2010.

SANTOS, C. F. Jovens, consumo e identidade: uma trilogia contemporânea.: Observatório Permanente da Juventude do ICS-UL: 16 p. 2011.

SANTOS, F. A. D. S. N. D. Juventude, Consumo e Globalização: Uma Análise Comparativa: Instituto Superior de Ciências do Trabalho e da Empresa: 391 p. 2004.

UNIRC, C. R. D. I. D. N. U. ALGUNS DADOS SOBRE A JUVENTUDE 2001.

Original recebido em: 30/10/2012

Aceito para publicação em: 03/12/2012

\section{Resumo sobre autor}

Lídia Oliveira é Professora Auxiliar com Agregação no Departamento de Comunicação e Arte da Universidade de Aveiro-Portugal. Doutorada em Ciências e Tecnologias pela Universidade de Aveiro-Portugal (2002). Investigadora e Coordenadora Científica do CETAC.MEDIA - Centro de Estudo das Tecnologias e Ciências da Comunicação

Carlos Reis é Licenciado em Teologia pela Universidade Católica Portuguesa (1996). Mestre em Comunicação Multimídia, Ramo Audiovisual, no Departamento de Comunicação e Arte (DeCA) da Universidade de Aveiro (2011). Profissionalmente é Técnico Superior na Câmara Municipal de ÁguedaPortugal, na Divisão de Estratégia e Planeamento, realizando funções na área da Comunicação Institucional.

Vania Baldi é Professor Auxiliar convidado no Departamento de Comunicação e Arte da 
Universidade de Aveiro-Portugal. Doutorado em "Ética e Antropologia. História e fundação" pelo departamento de "Filosofia e Ciências sociais" da Universidade do SalentoItália. Investigador do CETAC.MEDIA Centro de Estudo das Tecnologias e Ciências da Comunicação - http://www.cetacmedia.org/ e do CES - Centro de Estudos Sociais Laboratório Associado - http://www.ces.uc.pt/ 